\title{
Neonatal castration affects intrathymic kinetics of T-cell differentiation and the spleen T-cell level
}

\author{
K Radojević ${ }^{\text {, N Arsenović-Ranin }}{ }^{3}$, D Kosec ${ }^{1}$, V Pešić ${ }^{2}$, I Pilipović ${ }^{1}$, M Perišić ${ }^{1}$, B Plećaš-Solarović ${ }^{2}$ \\ and $\mathbf{G}$ Leposavić ${ }^{1,2}$ \\ ${ }^{1}$ Institute of Immunology and Virology 'Torlak', Immunology Research Centre 'Branislav Janković', Belgrade, Serbia \\ ${ }^{2}$ Department of Physiology, ${ }^{3}$ Department of Immunology and Microbiology, Faculty of Pharmacy, 450 Vojvode Stepe, 11221 Belgrade, Serbia \\ (Requests for offprints should be addressed to G Leposavić; Email: gordana.leposavic@pharmacy.bg.ac.yu)
}

\begin{abstract}
To test putative interdependence in the ontogenesis of the hypothalamic-pituitary-gonadal and thymic-lymphatic axes, thymocyte differentiation and maturation was examined in neonatally castrated $(\mathrm{Cx})$ adult rats. In the hypercellular thymi of $\mathrm{Cx}$ rats, the proportion of the least mature $\mathrm{CD} 4^{-} \mathrm{CD} 8^{-} \mathrm{TCR} \alpha \beta^{-}$triple negative (TN) thymocytes was reduced, while the proportions of all downstream double positive (DP) subsets $\left(\mathrm{TCR} \alpha \beta^{-}, \mathrm{TCR}_{\alpha} \beta^{\text {low }}\right.$ and TCR $\alpha \beta^{\text {high }}$ ) were increased when compared with neonatally sham-castrated $(\mathrm{Sx})$ adult rats. This suggested an accelerated thymocyte transition from the TN to DP TCR $\alpha \beta^{\text {low }}$ developmental stage accompanied by an increased positive/ reduced negative thymocyte selection. The increased thymocyte surface density of Thy- 1 , which is implicated in thymocyte hyposensitivity to negative selection, in $\mathrm{Cx}$ rats further supports the previous assumption. The finding that the proportions of both single positive (SP) TCR $\alpha \beta^{\text {high }}$
\end{abstract}

thymocyte subsets were reduced, while their numbers were increased $\left(\mathrm{CD} 4^{+} \mathrm{CD} 8{ }^{-}\right)$or unaltered $\left(\mathrm{CD} 4^{-} \mathrm{CD} 8^{+}\right)$, coupled with results demonstrating an increased level of $\mathrm{CD} 4{ }^{-} \mathrm{CD} 8{ }^{+}$cells without changes in that of $\mathrm{CD} 4{ }^{+} 8^{-}$cells in the spleen indicate: (i) accelerated differentiation and maturation of the positively selected DP TCR $\alpha \beta^{\text {high }}$ thymocytes towards CD $4^{-} 8^{+}$TCR $\alpha \beta^{\text {high }}$ cells followed by increased emigration of the mature cells and (ii) decelerated differentiation and maturation towards $\mathrm{CD} 4{ }^{+} 8^{-} \mathrm{TCR} \alpha \beta^{\text {high }}$ cells in $\mathrm{Cx}$ rats. Furthermore, the unaltered proportion of intrathymically developing $\mathrm{CD} 4{ }^{+} \mathrm{CD} 25^{+} \mathrm{Foxp}^{+}{ }^{+}$regulatory cells in $\mathrm{Cx}$ rats, in light of putative hyposensitivity of thymocytes to negative selection suggesting reduced elimination of autoreactive cells, may provide a firm basis for understanding the reasons behind increased susceptibility of $\mathrm{Cx}$ rats to autoimmune disease induction.

Journal of Endocrinology (2007) 192, 669-682

\section{Introduction}

In its simplest form, effective T-cell-mediated immunity emanates from the expansion of specific T-cells activated in response to antigen. Therefore, any manipulation that changes the levels of peripheral T-cells and/or affects their activation may interfere with the host's ability to efficiently respond to antigen challenge.

In establishing and maintaining the peripheral T-cell pool, the thymus plays a critical role providing a microenvironment within which the T-cell precursors proliferate, differentiate and undergo selection processes to create a fully functional population of major histocompatibility complex (MHC)-restricted, self-tolerant T-cells (Shortman et al. 1991, Zamoyska \& Lovatt 2004). The intrathymic differentiation of conventional T-cell receptor (TCR) $\alpha \beta$ cells proceeds via a series of distinct maturation steps, each characterised by a unique pattern of gene expression and a specific array of cell surface proteins, including the TCR $\alpha \beta-$ CD3 complex, CD4 and CD8. Upon entry into the thymus,
T-cell precursors express neither the TCR $\alpha \beta-\mathrm{CD} 3$ complex nor the accessory molecules (CD4 and CD8), i.e. they are triple negative $(\mathrm{TN})$. As differentiation proceeds, they acquire both accessory molecules becoming $\mathrm{CD} 4^{+} \mathrm{CD} 8^{+}$ double positive (DP). At this stage, TCR $\alpha \beta-\mathrm{CD} 3$ is expressed at a low level on their cell membrane and as a consequence the cells become eligible for both positive and negative selection (Zamoyska \& Lovatt 2004). Thymocytes expressing functional TCR $\alpha \beta-\mathrm{CD} 3$ interact with peptides presented by $\mathrm{MHC}$ on the membranes of non-lymphoid cells, and if the resulting avidity of $\mathrm{MHC} /$ peptide-TCR interactions reaches threshold level, the thymocytes receive survival signals and further increase TCR $\alpha \beta-\mathrm{CD} 3$ expression (positive selection). However, if the avidity is too high or too low, the thymocytes are functionally inactivated or deleted by apoptosis (negative selection) or die by neglect respectively. The cells that survive thymic selection further differentiate to either $\mathrm{CD} 4{ }^{+} \mathrm{CD} 8{ }^{-}$or $\mathrm{CD} 4{ }^{-} \mathrm{CD} 8^{+}$single positive (SP) mature cells and leave the thymus (Zamoyska \& Lovatt 2004). 
It has been suggested that androgens generally blunt the T-cell-dependent immune response. In the absence of androgens, the opposite effect is observed (Olsen \& Kovacs 1996, Verthelyi 2001). Although androgens have been implicated as negative modulators of host immunity, the precise mechanism(s) responsible for the bolstering effect of androgen deprivation on host immunity remain(s) to be fully determined. It is assumed that androgens most likely exert their effects on thymocytes, rather than on mature T-effector cells, because androgen receptors (ARs) have not been detected in peripheral organs of the immune system (Kovacs \& Olsen 1987, Takeda et al. 1990), but are present in rodent and human thymi (Sasson \& Mayer 1981, Kovacs \& Olsen 1987, Viselli et al. 1995). Furthermore, it has been suggested that androgens, besides their direct effects on the thymus via ARs, may exert indirect effects on the thymus via negative feedback action on gonadotrophinreleasing hormone $(\mathrm{GnRH})$ and pituitary gonadotrophin secretion (Rouabhia et al. 1989).

Androgen removal by castration before puberty increases thymic weight throughout puberty in rodents, while androgen administration prevents castration-induced thymic hypertrophy (Utsuyama \& Hirokawa 1989, Windmill et al. 1993, Leposavić et al. 1995). Furthermore, changes in thymus weight and its cellularity produced by alterations in the circulating androgen level are followed by alterations in the distribution of thymocyte subsets (Aboudkhil et al. 1991, Olsen et al. 1991, Windmill et al. 1993, Leposavić et al. 1995) which differ depending on their maturational stage at the point of hormone deprivation and its duration (Utsuyama et al. 1995).

However, despite the facts indicating that: (i) in rodents, the sexually dimorphic organisation of hypothalamic centres controlling gonadotrophin secretion arise as a result of the presence or the absence of androgens during the first 5 postnatal days (Beyer 1987) and (ii) gonadal hormones may be essential, timely and critical agents which in a sexually dimorphic manner, render immune cells capable of modifying their intrinsic potential, especially by their ability to differentiate (Pierpaoli et al. 1977, Morale et al. 1991), data within the literature concerning the effects of neonatal androgen ablation on the thymus and the T-cell-dependent immune response are extremely limited. We found that neonatal castration produced an increase in both thymic weight and cellularity in adult rats and hypothesised that the androgen status during the early postnatal period may be critical for programming postnatal thymic development (Leposavić et al. 1995). To test this hypothesis, the thymocyte subset composition was examined in neonatally castrated $(\mathrm{Cx})$ rats to: (i) ascertain whether thymic hyperplasia in neonatally Cx rats (Leposavić et al. 1995) involved a global increase across T-cell development or targeted-specific enhancing points leading to depletion of cells at one particular stage and accumulation of others beyond that stage and (ii) visualise effects of early postnatal gonadal ablation on the levels of T-cell subsets within the periphery.

\section{Materials and Methods}

\section{Animals}

Ten pregnant $\mathrm{AO}$ rats, born and maintained in the vivarium belonging to the Immunology Research Centre 'Branislav Janković' in Belgrade, were selected for the present study. The date of birth was designated as 'postnatal day 0'. The litter size was equated to six animals by cross-fostering pups. The litters and their mothers were raised in a temperature- and lightcontrolled animal room. Laboratory chow and tap water were available ad libitum. The rats were weaned at postpartal day 21 . Male offspring were assigned randomly for castration (Cx rats) or sham castration ( $\mathrm{Sx}$ rats).

\section{Experimental protocol}

Rats were castrated at postnatal day 3 using refrigerating anaesthesia. Bilateral castration was performed via a transverse scrotal incision allowing exposure of the testicles and transection of spermatic cords. Sham castration followed the same procedure except that pericordal fat was resected in lieu of the testicles. Three months after surgery, both $\mathrm{Cx}$ and Sx rats were killed, their thymi and spleens were carefully removed and freed from extraneous tissue, weighed and appropriately processed for flow cytometric analysis (FCA). All animal experimentation was conducted under local ethical guidelines and approved by the Institutional Animal Care and Use Committee.

Each thymus was aseptically isolated, trimmed of all excess body fat and gently blotted onto sterile gauze to remove excess blood. The thymus and spleen tissues were dissociated by gently grinding the tissue on a sterile $60 \mu \mathrm{m}$ sieve screen in complete RPMI-1640 medium. Erythrocytes were lysed by the addition of an isotonic solution of ammonium chloride (warmed to room temperature) to spleen cell samples in a volume ratio of 1:5. The resulting cell suspensions were washed thrice in ice-cold complete RPMI-1640 medium. The cells were then counted in an enhanced Neubauer haemocytometer and the number of cells per thymus (spleen) was estimated. The viability of such cell preparations, determined by Trypan blue exclusion, was routinely $>95 \%$.

\section{Serum testosterone levels}

Blood was taken from 3-day-old non-castrated rat pups and 3-month-old Sx rats by cardiac puncture. Thereafter, the serum was separated and stored at $-20^{\circ} \mathrm{C}$ until the RIA was performed. Serum testosterone was quantitated (in duplicate) using a commercial testosterone kit (INEP-DIJAGNOSTIKA, Zemun, Serbia). The RIA procedures were carried out according to the guidelines provided by the kit producer. Testosterone levels of $0 \cdot 3 \pm 0 \cdot 01 \mathrm{ng} / \mathrm{ml}$ (mean \pm s.E.M.) and $2.60 \pm 0.5 \mathrm{ng} / \mathrm{ml}$ (mean \pm s.E.M.) were detected in sera from 3-day-old non-castrated rat pups and 3-month-old Sx rats 
respectively. However, in 3-month-old $\mathrm{Cx}$ rats testosterone levels were below the level of detectability $(0 \cdot 2 \mathrm{ng} / \mathrm{ml})$.

\section{Chemicals, antibodies and immunoconjugates}

Sodium azide, merocyanine (MC) 540 and concanavalin A (ConA) were purchased from Sigma-Aldrich (Taufkirchen, Germany). Dexamethasone (Dex) was obtained from Galenika (Zemun, Serbia).

RPMI-1640 powdered medium (Sigma-Aldrich) was dissolved in redistilled water according to the manufacturer's instructions. To prepare complete RPMI medium, $2 \mathrm{mM}$ L-glutamine (Serva, Heidelberg, Germany), $1 \mathrm{mM}$ sodium pyruvate (Serva), 100 units/ml penicillin (ICN, Costa Mesa, CA, USA), $100 \mu \mathrm{g} / \mathrm{ml}$ streptomycin (ICN) and $10 \%$ foetal calf serum (FCS; Gibco) were added. FCS was previously inactivated by heating the serum at $56{ }^{\circ} \mathrm{C}$ for $30 \mathrm{~min}$.

For staining, the following first-step monoclonal antibodies (mAbs) were used: phycoerythrin (PE)-conjugated anti-CD4 (clone W3/25, Serotec, Oxford, UK), fluorescein-isothiocyanate (FITC)-conjugated anti-CD8 (clone MRC OX-8, Serotec), peridinin chlorophyll protein (PerCP)-conjugated anti-TCR $\alpha \beta$ (clone R73, BD Biosciences Pharmingen, Mountain View, CA, USA), biotin-conjugated anti-CD25 (clone MRC OX-39, Serotec), PE-conjugated anti-CD90 (Thy-1.1; clone HIS 51, BD Biosciences Pharmingen) and biotin-conjugated anti-CD3 (clone G4.18, BD Biosciences Pharmingen). The following second-step reagents were used: streptavidin-PerCP and streptavidin-PE. Appropriate IgG isotype controls were obtained from $\mathrm{BD}$ Biosciences Pharmingen.

\section{Phenotyping lymphocytes by FCA}

Detection of surface markers Staining of thymocytes and splenocytes was performed as previously described (Leposavić et al. 2005). Briefly, aliquots of $1 \times 10^{6}$ lymphoid cells (thymocytes or splenocytes rendered erythrocyte free) in $100 \mu \mathrm{l} \mathrm{RPMI}-1640$ medium were centrifuged at $350 \mathrm{~g}$ for $5 \mathrm{~min}$ at $4{ }^{\circ} \mathrm{C}$ to yield a pellet. The cells were incubated for $30 \mathrm{~min}$ on ice in the dark with fluorochrome-conjugated $\mathrm{mAbs}$ (direct staining) or with biotin-conjugated $\mathrm{mAbs}$ and fluorochrome-conjugated streptavidin (indirect staining) before being washed thrice using RPMI-1640 medium. When biotin-conjugated mAbs were used, the cells were incubated again for $30 \mathrm{~min}$ on ice with the appropriate fluorochrome-conjugated streptavidin. After staining, the cells were washed twice using RPMI-1640 medium and then in ice-cold PBS ( $\mathrm{pH} \mathrm{7 \cdot 4)}$ containing 0.09\% sodium azide. Twenty thousand cells per sample were analysed on the same day using a FACScan flow cytometer (Becton Dickinson, Mountain View, CA, USA). Non-specific IgG isotypematched controls were used for each fluorochrome type to define background staining, while dead cells and debris were excluded from analysis by selective gating based on anterior and right-angle scatter. The percentage of positive cells for each staining was determined using CellQuest Software (Becton Dickinson). Final estimates of marker-positive lymphocytes within each lymphoid organ were calculated according to the following formula:

[(cells in suspension $/ \mathrm{ml} \times$ total suspension volume $)$

$$
\times \text { percentage of marker }- \text { positive lymphocytes }] \times \frac{1}{100}
$$

In addition, CD90 expression on thymocytes was analysed by estimation of the mean channel number that represents the density of the surface marker expression. The mean channel number was determined for thymocytes from both $\mathrm{Cx}$ and $\mathrm{Sx}$ rats. The relative change in the mean fluorescence intensity (MFI) was calculated according to the following formula:

(MFI of the histogram of Cx rats - MFI of the histogram of Sx rats) $\times 100$ MFI of the histogram of Sx rats

(Kamath et al. 1998).

Detection of intracellular markers After CD4 and CD25 staining, which was performed according to the surface staining protocol, thymocytes were subjected to staining for Foxp3 using a commercial Foxp3 staining kit (eBioscience, San Diego, CA, USA) containing FITCconjugated anti-Foxp3 mAbs (clone FJK-16s) according to the manufacturer's instructions. Lymphocytes from inguinal lymph nodes were used as positive controls to validate Foxp3 reactivity. Twenty thousand cells per sample were analysed using the FACScan flow cytometer and CellQuest Software.

\section{Detection of apoptotic thymocytes}

Since apoptotic thymocytes are normally rapidly eliminated by phagocytes in vivo, the relative number of apoptotic cells was quantified after $18 \mathrm{~h}$ of cultivation. This time point was elected because it allows an accurate assessment of apoptosis with acceptable background values (Kamath et al. 1998). Aliquots of $100 \mu \mathrm{l}$ freshly isolated thymocytes in complete RPMI-1640 medium $\left(5 \times 10^{6}\right.$ cells $\left./ \mathrm{ml}\right)$ were plated in 96-well flat-bottom plates (Nunc A/S, Roskilde, Denmark). To these cells, $100 \mu \mathrm{l}$ complete medium containing Dex were added to attain a final concentration of $100 \mathrm{nM}$ Dex, a dose known to induce apoptosis of rat thymocytes in vitro (Brown et al. 1993). In control cultures, $100 \mu$ complete medium were added. After $18 \mathrm{~h}$ of culture, the cells were harvested and apoptotic thymocytes were detected using MC540 lypophilic dye. Similar to annexin-V, MC 540 labels a decreased packing order of phospholipids in the outer leaflet of the apoptotic cell plasma membrane. The percentage of apoptotic cells labelled with MC540 has been shown to be equivalent to that obtained by annexin-V labelling (Laakko et al. 2002).

The staining was performed according to the procedure described by Mower et al. (1994). Briefly, just before FCA $5 \mu \mathrm{l}$ of $1 \mathrm{mg} / \mathrm{ml}$ MC540 solution in double-distilled $\mathrm{H}_{2} \mathrm{O}$ 
was added to $1 \mathrm{ml}$ thymocyte suspension containing $10^{6}-10^{7}$ cells. All samples were analysed using a FACScan flow cytometer and CellQuest Software. According to the intensity of MC540 fluorescence and forward scatter (Cohen 1991), two subsets of apoptotic cells can be distinguished: (1) cells in early apoptosis and (2) cells in advanced/late apoptosis. Cells in early apoptosis exhibit high level of MC540 staining, whereas those in advanced/late apoptosis show lower levels of MC540 staining and lower forward scatter.

\section{Detection of bromodeoxyuridine (BrdU)-positive $\left(\mathrm{BrdU}^{+}\right)$cells}

BrdU incorporation was employed to identify DNAsynthesising cells in vitro. A total of $2 \times 10^{5}$ thymocytes/well $(100 \mu \mathrm{l})$ were dispersed into plastic $96-$ well plates (Nunc A/S) and cultured for $48 \mathrm{~h}$ at $37^{\circ} \mathrm{C}$ in a $5 \% \mathrm{CO}_{2}$ humified air atmosphere without (ConA-) or with $2.5 \mu \mathrm{g} / \mathrm{ml}$ ConA $($ ConA +$)$ in a total volume of $200 \mu$ complete RPMI-1640 culture medium. Since it has been shown that in thymocyte cultures stimulated with ConA, there is significant interleukin (IL) -2 production and upregulation of the IL- $2 \mathrm{R} \alpha$ providing the second proliferative signal (Čolić et al. 2000) ConA was added alone. All cultures were performed in triplicate. During the last $18 \mathrm{~h}$ of culture, the cells were pulsed using $1 \mu \mathrm{M}$ BrdU. BrdU incorporation into cells was detected using the BrdU/7-AAD flow kit (BD Biosciences Pharmingen). The 7-AAD staining enabled the detection of the late apoptotic/ necrotic hypodiploid cells and subsequently their exclusion from the analysis. To determine the phenotypic characteristics of the $\mathrm{BrdU}^{+}$cells, staining with FITC-conjugated antiBrdU Abs and 7-AAD was combined with staining with biotin-conjugated anti-CD3 $\mathrm{mAbs}$ as a first-step reagent and streptavidin-PE as a second-step reagent. The staining was performed according to the BrdU/7-AAD flow kit producer's manual. All samples were analysed using a FACScan flow cytometer and CellQuest Software.

\section{Statistical analysis}

To assess the significance of differences between groups, the Mann-Whitney $U$ test was applied using the programme SPSS 10.0 for Windows. $P \leq 0 \cdot 05$ was considered significant.

\section{Results}

Neonatal castration increases thymic weight and cellularity in adult rats

In adult $\mathrm{Cx}$ rats, both absolute and relative (ratio to body weight) thymic weights were significantly increased compared with those in age-matched Sx controls (Table 1). Furthermore, thymi from $\mathrm{Cx}$ rats contained a significantly greater number of thymocytes than those from $\mathrm{Sx}$ rats and the relative cellularity of these thymi (ratio to body weight) was significantly augmented compared with those from Sx rats (Table 1).

Neonatal castration diminishes the percentage of apoptotic cells in thymocyte cultures from adult rats

To assess the putative contribution of alteration in thymocyte apoptosis to thymic hypercellularity in Cx rats, the percentage of apoptotic cells in thymocyte cultures was measured. Figure 1 indicates that Dex significantly augmented the percentage of apoptotic cells in thymocyte cultures from both $\mathrm{Cx}$ and Sx rats. However, regardless of the presence of Dex, the percentage of apoptotic cells was lower in thymocyte cultures from $\mathrm{Cx}$ rats compared with those from $\mathrm{Sx}$ rats. In both Dex + and Dex - thymocyte cultures, the decrease in the percentage of apoptotic cells reflected a drop in the relative number of cells in the early phase of apoptosis. Therefore, our results clearly indicated that androgen hormone deprivation rendered thymocytes less prone to induction of apoptosis.

Neonatal castration increases the percentage of $\mathrm{BrdU}^{+}$cells in the absence but not in the presence of $\operatorname{Con} A$ in thymocyte cultures from adult rats

To further clarify the mechanism(s) responsible for the increased cellularity of thymi from $\mathrm{Cx}$ rats, the overall frequency of $\mathrm{BrdU}^{+}$thymocytes and the frequency of $\mathrm{BrdU}^{+}$cells within thymocyte subsets defined by surface density of $\mathrm{CD} 3\left(\mathrm{CD}^{-}, \mathrm{CD} 3^{\text {low }}\right.$ and $\left.\mathrm{CD} 3^{\text {high }}\right)$ were examined in ConA - and ConA + thymocyte cultures. In the absence of ConA, the percentage of $\mathrm{BrdU}^{+}$cells was significantly greater in thymocyte cultures from $\mathrm{Cx}$ rats than in cultures from $\mathrm{Sx}$ rats (Fig. 2A). ConA significantly

Table 1 Increased absolute and relative thymic weight as well as total and relative thymocyte number in 3-month-old neonatally castrated rats $(\mathrm{Cx})$ compared with age-matched sham-castrated rats $(\mathrm{Sx})$

Absolute thymus weight
(g); median (25th-75th
percentiles)

Treatment

Sx $(n=8)$

$\mathrm{Cx}(n=6)$
Relative thymus weight (g/100 g bw); median (25th-75th percentiles)
Total thymocyte number $\left(\times 10^{7}\right)$ /thymus; median (25th-75th percentiles)
Relative thymocyte number $\left(\times 10^{7}\right) / 100 \mathrm{~g}$ bw; median (25th-75th percentiles)

The table indicates data from a single experiment. Very similar data were obtained in an identically performed independent experiment. ${ }^{*} P<0 \cdot 001$; bw, body weight. 
increased the percentage of $\mathrm{BrdU}^{+}$cells in thymocyte cultures from both $\mathrm{Cx}$ and $\mathrm{Sx}$ rats (Fig. 2A) in such a way that the percentage of $\mathrm{BrdU}^{+}$cells did not significantly differ between thymocyte cultures from $\mathrm{Cx}$ and $\mathrm{Sx}$ rats.

A
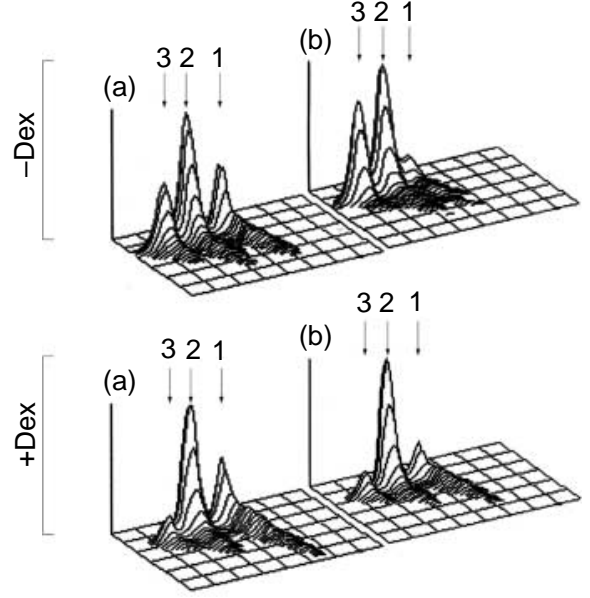

B

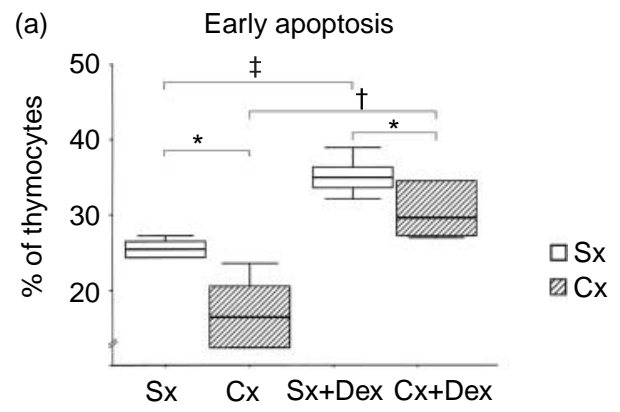

(b) Advanced/late apoptosis
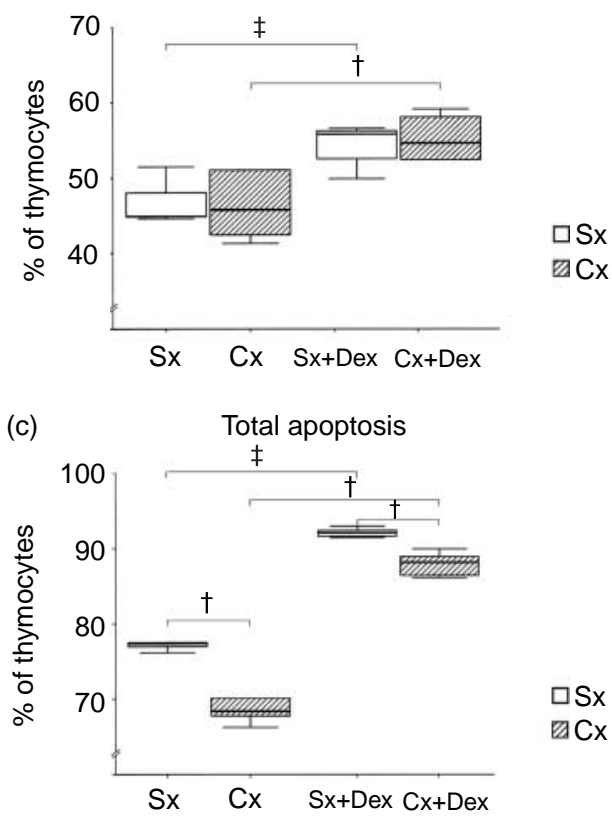

Irrespective of the presence of ConA in thymocyte cultures from both $\mathrm{Cx}$ and $\mathrm{Sx}$ rats, $\mathrm{BrdU}^{+}$cells were found in all subsets of cells defined by CD3 expression. As expected, since ConA has been shown to act on immature and mature T-cells by TCR cross-linking (Pongracz et al. 2003) causing survival and further maturation of the former and proliferation of the latter, in thymocyte cultures from both $\mathrm{Cx}$ and $\mathrm{Sx}$ rats, a significant increase in the percentage of $\mathrm{BrdU}^{+}$cells within $\mathrm{CD}^{\text {low }}$ and $\mathrm{CD} 3^{\text {high }}$ cell subset was found (Fig. 2B). Irrespective of the ConA presence, the percentage of $\mathrm{BrdU}^{+}$within none of the cell subsets defined by CD3 expression significantly differ between $\mathrm{Cx}$ and $\mathrm{Sx}$ rats (Fig. 2B).

Neonatal castration affects distribution of thymocyte subsets delineated by expression of CD4/8/TCR $\alpha \beta$

Figure 3 indicates that thymocyte suspensions from both $\mathrm{Cx}$ and $\mathrm{Sx}$ rats displayed three distinct surface levels of the TCR $\alpha \beta-C D 3$ complex by fluorescent staining with R73 mAbs: (i) high (TCR $\left.\alpha \beta^{\text {high }}\right)$, (ii) low $\left(\right.$ TCR $\alpha \beta^{\text {low }}$ ) and (iii) an undetectable level $\left(\mathrm{TCR} \alpha \beta^{-}\right)$. With respect to the expression of CD4 and CD8 in combination with the level of TCR $\alpha \beta$ expression, 12 subsets of thymocytes were delineated (Leposavic et al. 2005) and the relative and absolute numbers of the thymocytes belonging to each of them were quantified.

TCR $\boldsymbol{\alpha} \boldsymbol{\beta}^{-}$subsets Neonatal castration led to profound changes in the relative numbers of TCR $\alpha \beta^{-}$thymocyte subsets delineated by CD4/CD8 expression. The relative number of the least mature $\mathrm{DN}$ and that of $\mathrm{CD} 4^{+} \mathrm{CD} 8^{-} \mathrm{SP}$ cells were significantly decreased. In contrast, the relative number of DP cells and that of $\mathrm{CD}^{-} \mathrm{CD}^{+} \mathrm{SP}$ cells were significantly increased in Cx rats compared with Sx rats (Figs 3 and 4A).

Figure 1 Neonatal castration decreases the percentage of apoptotic cells in thymocyte cultures from 3-month-old adult rats castrated at postnatal day $3(\mathrm{Cx})$. In 18-h cultured thymocytes from $\mathrm{Cx}$ rats and age-matched sham-castrated control rats $(\mathrm{Sx})$, the percentage of apoptotic cells, in the presence of dexamethasone (+Dex) and in the absence of Dex (-Dex), was assessed using MC540 and flow cytometric analysis. (A) Three-dimensional plots of MC540-stained thymocytes in +Dex and -Dex cultures from Sx rats (a) and Cx rats (b). According to the intensity of MC540 thymocyte staining and forward scatter (FSC), two subsets of cells at distinct phases of apoptosis (early apoptosis and advanced/late apoptosis) were delineated. 1, early apoptosis; 2, advanced/late apoptosis and 3, alive cells. (B) Overall percentage of apoptotic cells in early (a) and advanced/late apoptosis (b) as well as total percentage of apoptotic cells (c) in thymocyte cultures from Cx rats and Sx rats. The results are presented as box plots with the central line representing the sample median and lower and upper borders of the box representing the 25th and 75 th percentiles respectively. The lower and the upper lines indicate minimal and maximal values of the sample respectively. The figure indicates data from a single experiment performed with six $C x$ rats and eight Sx rats. Very similar data were obtained in an identically performed independent experiment. ${ }^{*} P<0 \cdot 05 ;{ }^{\dagger} P<0 \cdot 01,{ }^{\ddagger} P<0 \cdot 001$. 
A $\square \mathrm{Sx} \square \mathrm{Cx}$

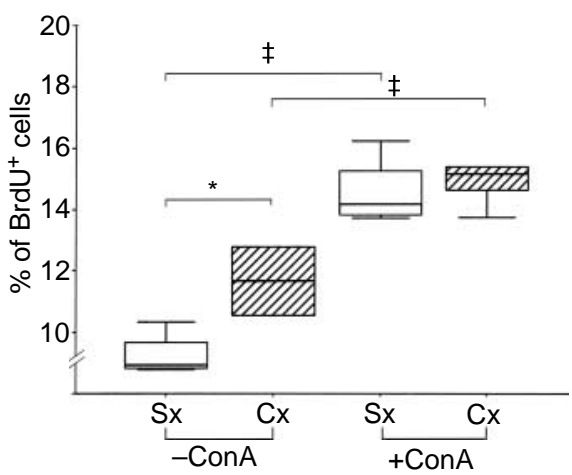

B $\square S x \quad C x$
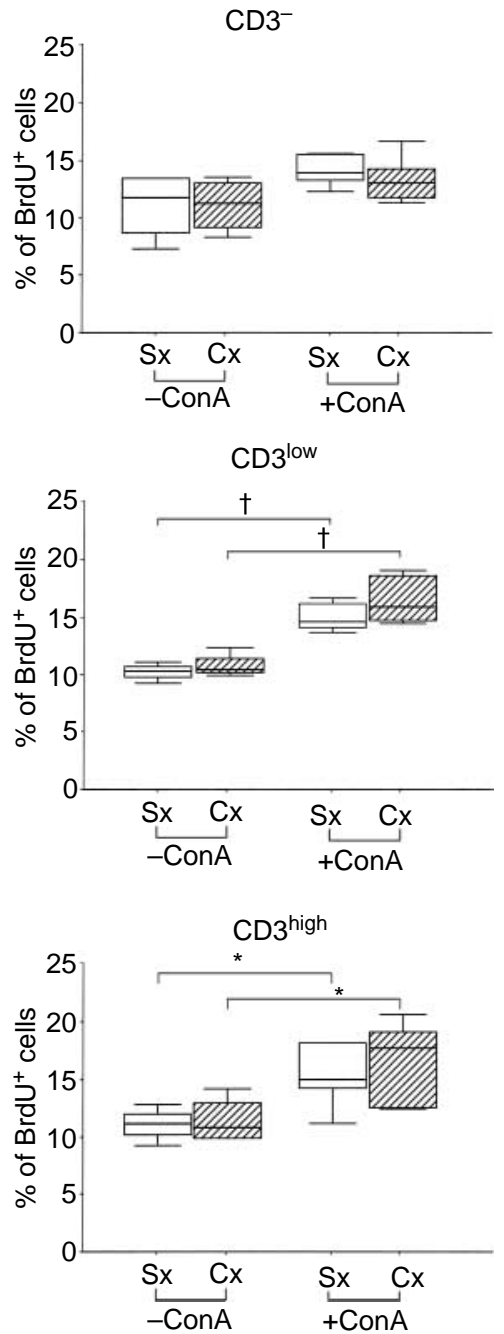

Journal of Endocrinology (2007) 192, 669-682
In Cx rats, due to a significant increase in thymocyte yield, the absolute cell number was increased across all TCR $\alpha \beta^{-}$ subsets, except for the $\mathrm{CD} 4^{+} \mathrm{CD} 8^{-}$subset, which was significantly decreased (Fig. 4B).

TCR $\alpha \boldsymbol{\beta}^{\text {low }}$ subsets In Cx rats, the percentage of DP cells, which are believed to represent the thymocyte subset entering the selection processes (Zamoyska \& Lovatt 2004), was significantly increased in comparison with Sx rats (Figs 3 and $4 \mathrm{~A})$. The percentage of $\mathrm{CD}^{-}{ }^{-} \mathrm{CD} 8^{+} \mathrm{SP}$ cells, which as SP TCR $\alpha \beta^{-}$cells are believed to emerge along the developmental route from the DN TCR $\alpha \beta^{-}$to the DP TCR $\alpha \beta^{\text {low }}$ stage (Petrie et al. 1990, Leposavić et al. 2005), was significantly increased, whereas that of $\mathrm{CD} 4{ }^{+} \mathrm{CD} 8^{-} \mathrm{SP}$ cells was significantly reduced (Figs 3 and $4 \mathrm{~A}$ ). The relative number of $\mathrm{DN}$ cells remained unaffected by neonatal castration (Figs 3 and 4A).

In $\mathrm{Cx}$ rats, numerical increases were found within all thymic subsets, except for the $\mathrm{CD} 4{ }^{+} \mathrm{CD} 8{ }^{-}$subset which indicated a reduction (Fig. 4B).

TCR $\boldsymbol{\alpha} \boldsymbol{\beta}^{\text {high }}$ subsets In Cx rats, the percentage of DP cells, which are believed to be at the intermediate stage of development between the DP TCR $\alpha \beta^{\text {low }}$ and the most mature SP TCR $\alpha \beta^{\text {high }}$ stage (Shortman et al. 1991, Zamoyska \& Lovatt 2004), was significantly increased. However, the percentage of DP TCR $\alpha \beta^{\text {high }}$ cell descendents $\mathrm{CD} 4^{+} \mathrm{CD} 8^{-}$ and $\mathrm{CD} 4^{-} \mathrm{CD}{ }^{+} \mathrm{SP}$ cells was significantly reduced in the thymus of Cx rats (Figs 3 and 4A). The percentage of cells belonging to the small subset of DN thymocytes did not differ between Cx and Sx rats (Figs 3 and 4A).

The absolute number of DP cells was significantly greater in $\mathrm{Cx}$ rats than in Sx rats (Fig. 4B). However, although the percentage of both $\mathrm{CD} 4{ }^{+} \mathrm{CD} 8{ }^{-}$and $\mathrm{CD} 4{ }^{-} \mathrm{CD} 8^{+}$cells of SP thymocytes was significantly reduced, the absolute number of $\mathrm{CD} 4^{+} \mathrm{CD} 8^{-}$SP cells was significantly increased, while that of $\mathrm{CD}^{-} \mathrm{CD}^{+} \mathrm{SP}$ cells remained unaltered (Fig. 4B). The absolute number of DN cells did not significantly differ between $\mathrm{Cx}$ rats and Sx rats (Fig. 4B).

Figure 2 Neonatal castration increases the percentage of $\mathrm{BrdU}^{+}$ cells only in ConA-free thymocyte cultures. (A) Percentages of all $\mathrm{BrdU}^{+}$cells in thymocyte cultures from 3 -month-old adult rats castrated at postnatal day $3(\mathrm{Cx})$ and age-matched sham-castrated control rats ( $\mathrm{Sx}$ ) and $(\mathrm{B})$ percentages of $\mathrm{BrdU}^{+}$cells within different cell subsets delineated according to the intensity of $\mathrm{CD} 3$ staining $\left(\mathrm{CD} 3^{-}, \mathrm{CD} 3^{\text {low }}\right.$ and $\left.\mathrm{CD} 3^{\text {high }}\right)$ determined by flow cytometric analysis. The thymocytes were cultured in medium without ConA $(-$ Con $\mathrm{A})$ or with ConA $(+$ ConA). The results are presented as box plots with the central line representing the sample median and lower and upper borders of the box representing the 25th and 75th percentiles respectively. The lower and the upper lines indicate minimal and maximal values of the sample respectively. The figure indicates data from a single experiment performed with six Cx rats and eight $S x$ rats. Very similar data were obtained in an identically performed independent experiment. ${ }^{*} P<0 \cdot 05,{ }^{\dagger} P<0 \cdot 01, P<0 \cdot 001$. 
A

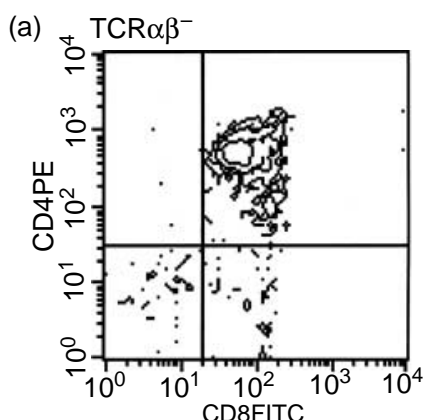

B

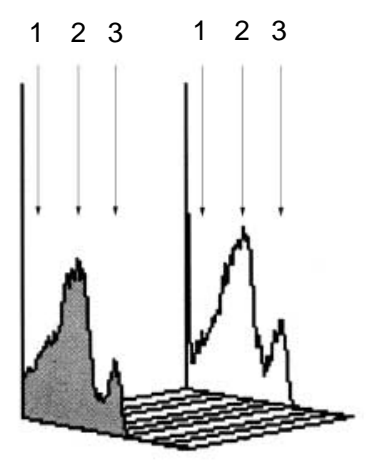

C

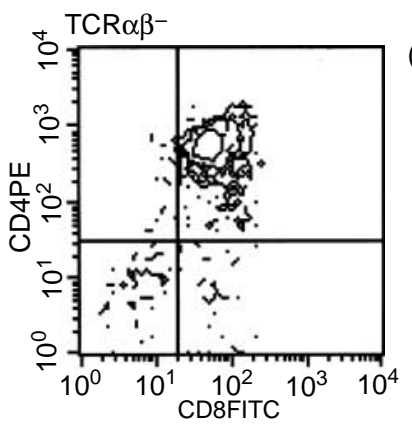

(a) (b)

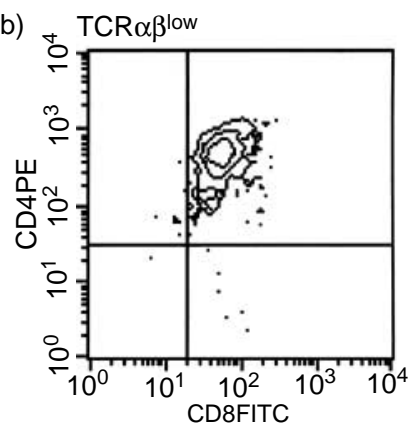

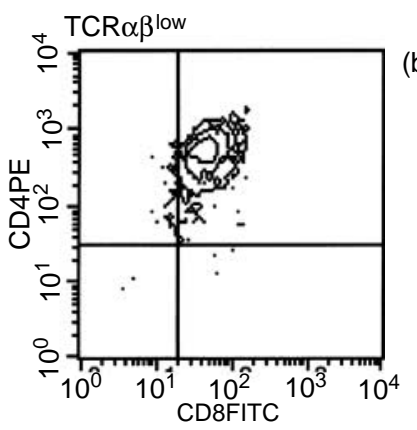

(c)

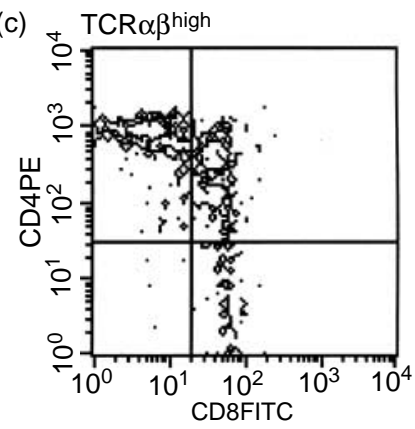

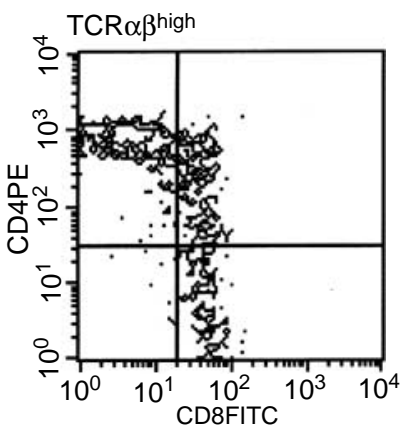

(b)

Figure 3 Three-colour flow cytometric analysis of thymocyte staining with anti-CD4PE, anti-CD8FITC and anti-TCR $\alpha \beta$ PerCP mAbs from 3-month-old adult rats castrated at postnatal day 3 (Cx) (A) and age-matched sham-castrated control rats $(\mathrm{Sx})(\mathrm{C})$. In each panel, contour plots represent CD4 and CD8 expression on gated (a) TCR $\alpha \beta^{-}$(b) TCR $\alpha \beta^{\text {low }}$ and (c) TCR $\alpha \beta^{\text {high }}$ thymocytes. The histogram plot (B) represents flow cytometric profiles of TCR $\alpha \beta$ staining of thymocytes from $C x$ rats (grey histogram) and Sx rats (white histogram). 1, TCR $\alpha \beta^{-}$cells; 2, TCR $\alpha \beta^{\text {low }}$ cells and 3, TCR $\alpha \beta^{\text {high }}$ cells. Representative plots (from repeated experiments) are shown in the figure.

Neonatal castration produces an increase in both the percentage of $\mathrm{CD}^{+} 0^{+}$thymocytes and density of thymocyte surface CD90 expression in adult rats

The expression of CD90 (Thy-1), which is believed to be a molecule involved in the negative regulation of TCR $\alpha \beta$ signalling and thereby TCR-dependent selection thresholds (Hueber et al. 1997), on thymocytes was also examined. The percentage of $\mathrm{CD} 90^{+}$cells was significantly greater in Cx rats than in Sx rats. In addition, the MFI for CD90 was markedly elevated (196 $\pm 7 \%$ ) in Cx rats compared with Sx rats (Fig. 5).
MFI indicates the density of antigen expression on a per cell basis and it has been shown that a 100\% greater MFI represents a twofold greater surface antigen density (Kamath et al. 1998). Accordingly, the average density of CD90 expression was almost threefold greater in $\mathrm{Cx}$ rats compared with Sx rats.

We next analysed the expression of CD90 on TCR $\alpha \beta^{\text {low }}$ thymocytes (encompassing mainly cortical DP cells) and on $\mathrm{TCR} \alpha \beta^{\text {high }}$ thymocytes. Although in Cx rats the relative number of both $\mathrm{CD} 90^{+} \mathrm{TCR} \alpha \beta^{\text {low }}$ and $\mathrm{CD} 90^{+} \mathrm{TCR} \alpha \beta^{\text {high }}$ cells remained unaltered (data not shown), the MFI for CD90 was strikingly greater on both TCR $\alpha \beta^{\text {low }}(199 \pm 7 \cdot 5 \%)$ and 
$\mathrm{Sx} \otimes \mathrm{Cx}$
A

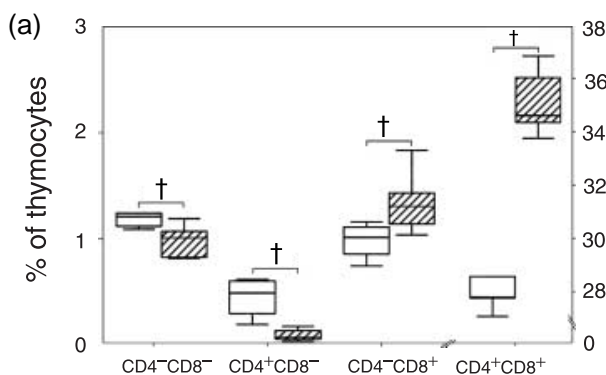

B
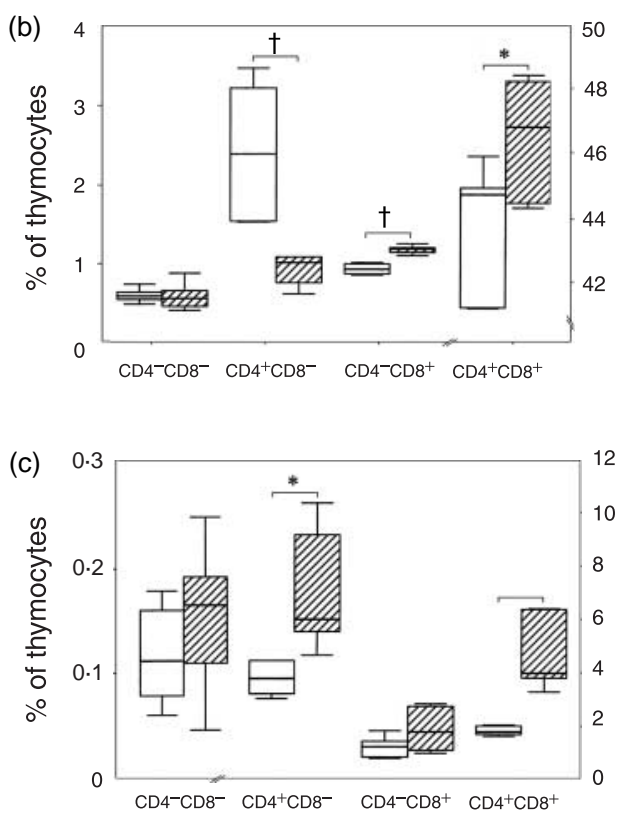

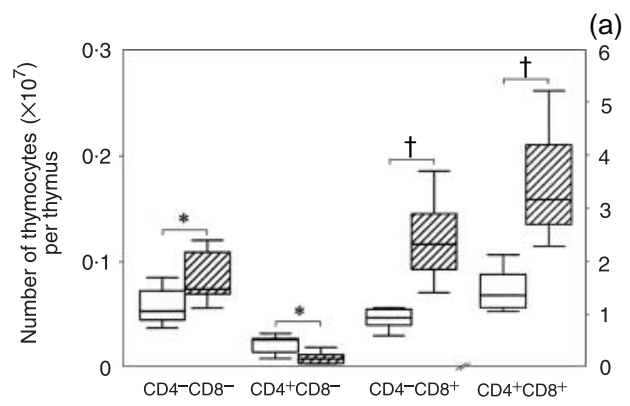

(b)

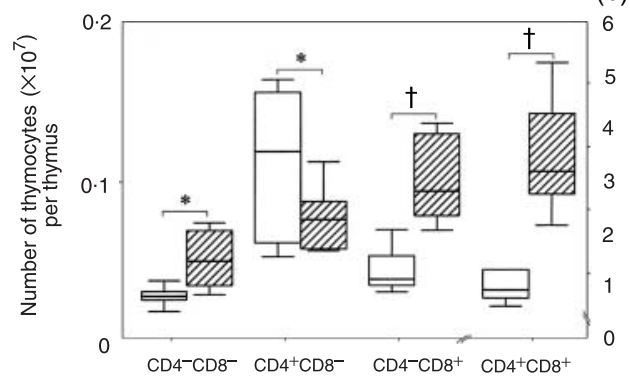

(c)

(a)

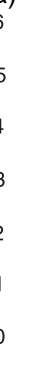

(b)

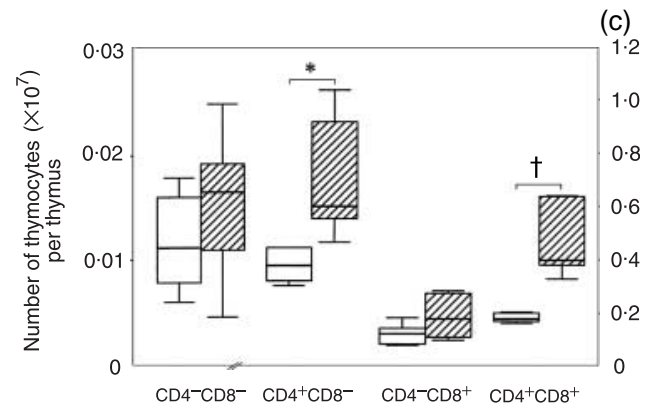

Figure 4 Neonatal castration affects the composition of thymocyte subsets in 3-month-old rats. Percentages (A) and absolute numbers (B) of TCR $\alpha \beta^{-}$(a) TCR $\alpha \beta^{\text {low }}$ (b) and TCR $\alpha \beta^{\text {high }}$ (c) thymocyte subsets delineated by expression of CD4 and CD8 in 3-month-old adult rats castrated at postnatal day 3 $(\mathrm{Cx})$ and age-matched sham-castrated control rats (Sx). The results are presented as box plots with the central line representing the sample median and lower and upper borders of the box representing the 25th and 75th percentiles respectively. The lower and the upper lines indicate minimal and maximal values of the sample respectively. The figure indicates data from a single experiment performed with six $\mathrm{Cx}$ rats and eight $\mathrm{Sx}$ rats. Very similar data were obtained in an identically performed independent experiment. ${ }^{*} P<0 \cdot 05 ;{ }^{\dagger} P<0 \cdot 01$.

TCR $\alpha \beta^{\text {high }}(94 \pm 6 \cdot 8 \%)$ cells (Fig. 5), suggesting that in Cx rats the average surface density of CD90 per thymocyte of TCR $\alpha \beta^{\text {low }}$ and TCR $\alpha \beta^{\text {high }}$ phenotype was almost three- and twofold greater respectively.

Neonatal castration has no effect on the percentage of $C D 4+$ CD25+ Foxp3 + thymocytes

Bearing in mind that the thymus generates $\mathrm{CD} 4{ }^{+}$ $\mathrm{CD} 25^{+}$Foxp $^{+}$regulatory T-cells (T reg), which have been shown to play a critical role in suppressing aberrant responses to self and consequently in preventing autoimmunity (Stephens $\&$
Ignatowicz 2003, Maggi et al. 2005), we quantified the relative and absolute numbers of $\mathrm{CD} 4{ }^{+} \mathrm{CD} 25^{+}{ } \mathrm{Foxp}^{+}$cells in thymi isolated from $\mathrm{Cx}$ and $\mathrm{Sx}$ rats. The percentage of these cells did not significantly differ between $\mathrm{Cx}$ and $\mathrm{Sx}$ rats. However, the absolute number of these cells was significantly greater in $\mathrm{Cx}$ rats than in Sx rats due to organ hypercellularity (Fig. 6).

\section{Neonatal castration increases spleen weight and cellularity in adult rats}

Neonatal castration produced a significant increase in both the absolute and the relative spleen weight (ratio to body weight; 
A (a)

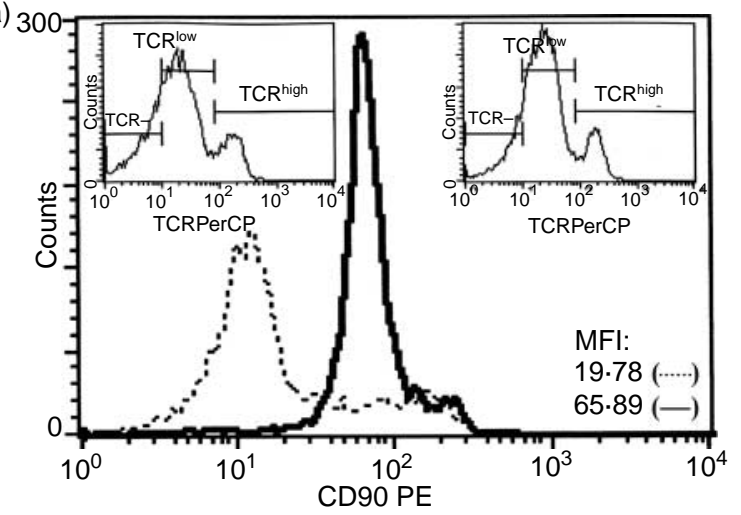

(b)

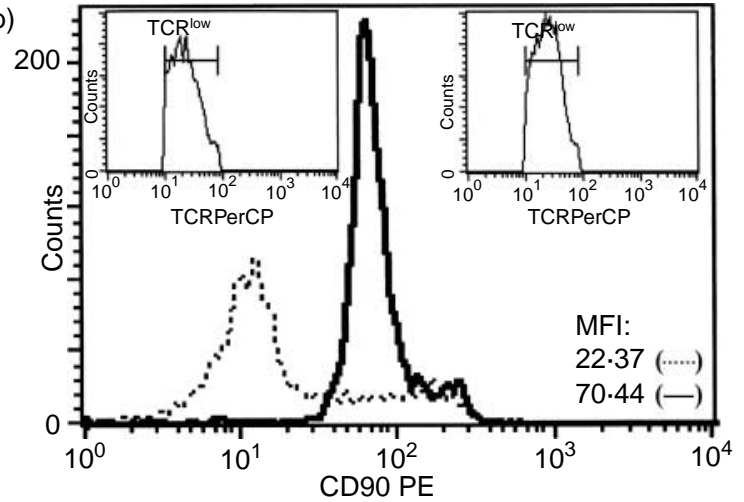

(c)

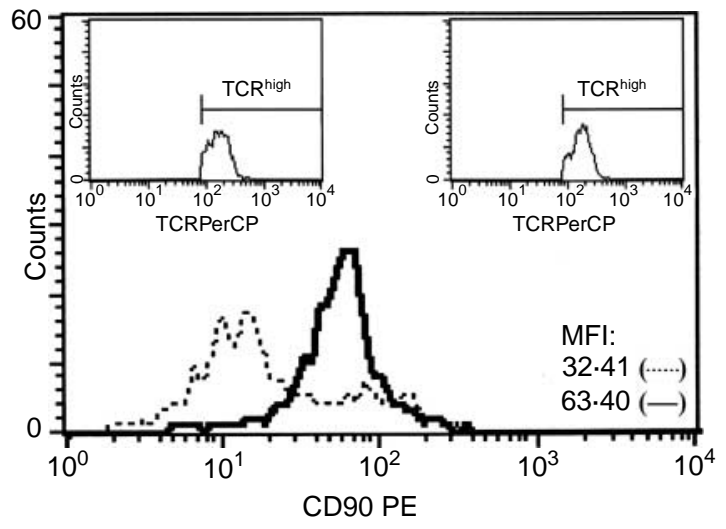

B

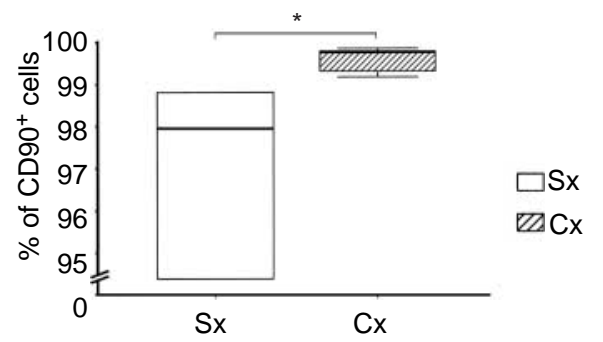

Table 2). The spleens from Cx rats contained a significantly greater number of lymphoid cells (Table 2). Moreover, the relative splenocyte number (relative to body weight) was also significantly $(P<0 \cdot 05)$ augmented in Cx rats (Table 2$)$.

\section{Neonatal castration increases total T-cell number and level of} $C D 4^{-} \mathrm{CD} 8^{+}$lymphoid cells within the spleen of adult rats

FCA of CD3 expression revealed a significant decrease in the percentage of $\mathrm{CD} 3+$ cells in the spleen of $\mathrm{Cx}$ rats compared with $\mathrm{Sx}$ rats (Table 3).

Since the total number of splenocytes was significantly increased in $\mathrm{Cx}$ rats, the spleens of these animals were found to contain significantly more $\mathrm{CD}^{+}$cells.

FCA of CD4/CD8 expression demonstrated that the decrease in the percentage of $\mathrm{CD} 3^{+}$cells mainly reflected a significantly diminished percentage of $\mathrm{CD} 4{ }^{+} \mathrm{CD} 8{ }^{-}$cells. The percentage of $\mathrm{CD} 4{ }^{-} \mathrm{CD} 8{ }^{+}$cells was not significantly affected by castration. However, due to a significant rise in the total number of splenocytes, the absolute number of $\mathrm{CD} 4^{-} \mathrm{CD} 8^{+}$ cells was significantly greater in $\mathrm{Cx}$ rats (Table 3 ), whereas that of $\mathrm{CD} 4^{+} \mathrm{CD} 8{ }^{-}$cells was increased, but this latter increase did not reach statistical significance (Table 3 ).

\section{Discussion}

Our study describes several novel observations pertaining to the role of gonadal hormones in regulating the development of the immune system. First, gonadal hormone ablation in neonatal rats affects thymic ontogenesis leading to: (i) a substantial increase in thymic cellularity, (ii) changes in the distribution of the major thymocyte subsets reflecting altered kinetics of the multi-step thymocyte differentiation process and (iii) increased Thy-1 surface density on thymocytes expressing TCR $\alpha \beta$ implying altered thymocyte selection thresholds. Secondly, neonatal castration increases spleen weight and its lymphoid cell content in adult rats partly due to a numerical expansion in the $\mathrm{CD} 8^{+} \mathrm{T}$ subset.

Figure 5 Neonatal castration increases the density of CD90 surface expression on thymocytes. (A) Representative overlaid histograms of the expression of CD90 on whole thymocyte population (a), gated TCR $\alpha \beta^{\text {low }}$ thymocytes (b) and TCR $\alpha \beta^{\text {high }}$ thymocytes (c) from neonatally castrated rats ( $\mathrm{Cx}$; solid line) and age-matched shamcastrated control rats (Sx; dotted line). Representative histograms of $\mathrm{TCR} \alpha \beta$ expression on thymocytes from $\mathrm{Sx}$ and $\mathrm{Cx}$ rats are inserted in the upper left and right corners of (a) respectively. Gates for $\mathrm{TCR} \alpha \beta^{\text {low }}(\mathrm{b})$ and TCR $\alpha \beta^{\text {high }}$ (c) cells were set as shown in histograms inserted in the upper left $(\mathrm{Sx})$ and upper right corner $(\mathrm{Cx})$ respectively. (B) The box plot represents the percentage of thymocytes expressing CD90 on Sx and Cx rats. The central box line represents the sample median, while lower and upper borders of the box representing the 25 th and 75 th percentiles respectively. The lower and the upper lines indicate minimal and maximal values of the sample respectively. The figure shows data from a single experiment in which six $C x$ and eight $S x$ rats were used. Two further identical experiments gave very similar results. ${ }^{*} P<0 \cdot 01$. 
A

(a)
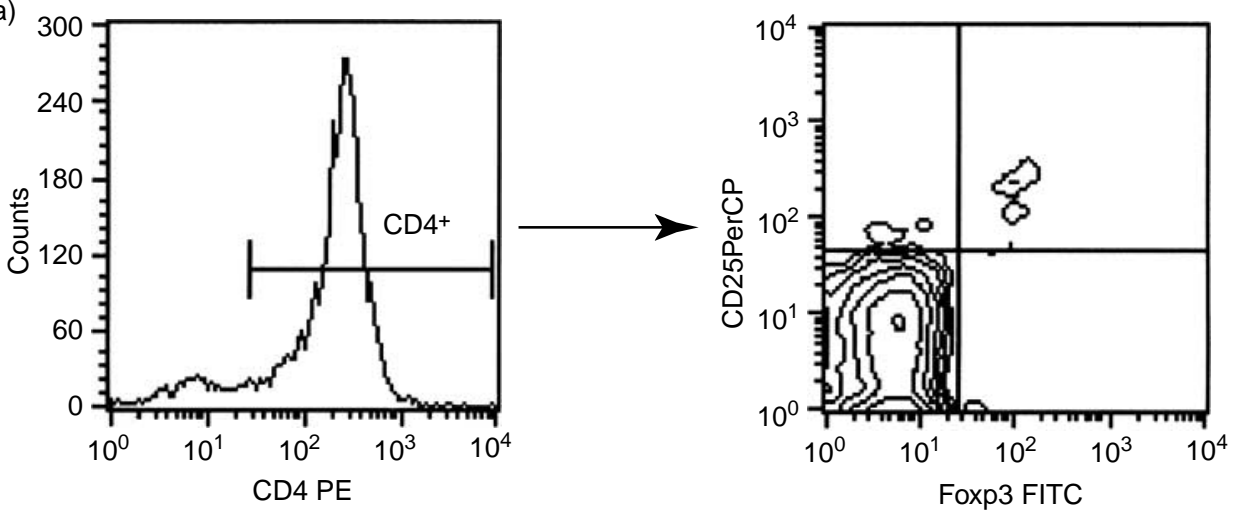

(b)
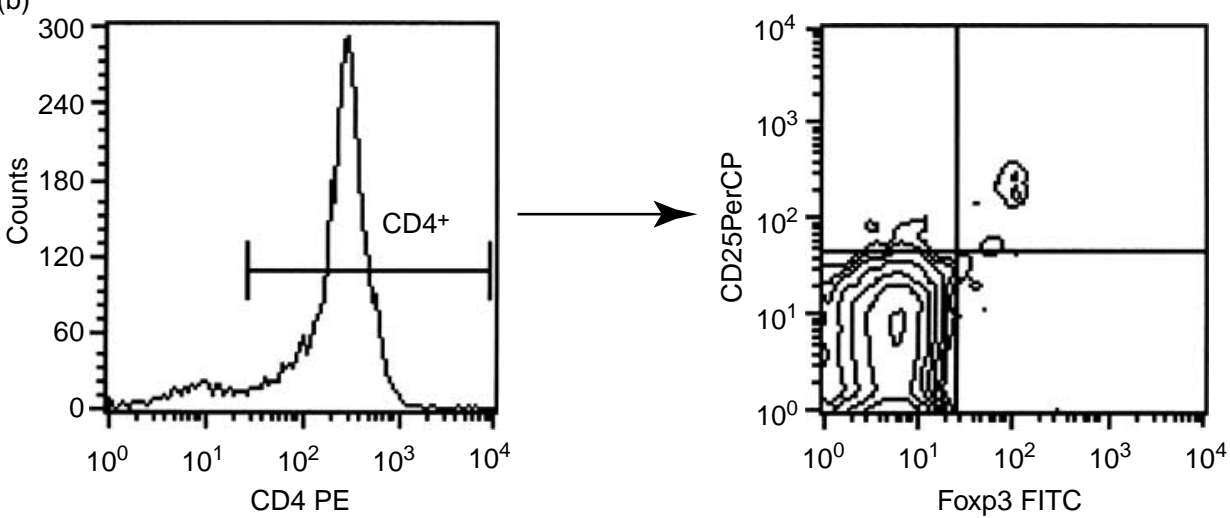

B

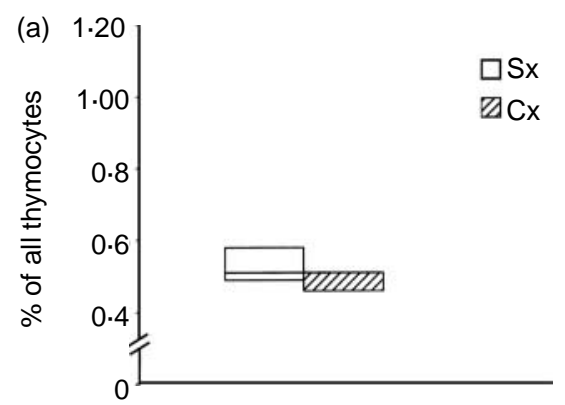

(b)

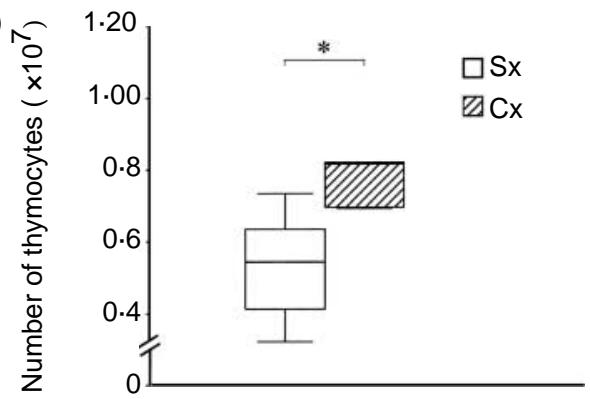

Figure 6 Neonatal castration does not affect the percentage of $\mathrm{CD} 4{ }^{+} \mathrm{CD} 25^{+}$Foxp $3^{+}$thymocytes in adult rats. (A) Flow cytometric analysis of CD25 and Foxp3 expression (right side) on CD4 ${ }^{+}$gated cells (left side) from 3-month-old sham-castrated control rats (Sx) (a) and castrated rats (Cx) (b). (B) The box plots represent the percentage (left) and absolute number (right) of the $\mathrm{CD} 4^{+} \mathrm{CD} 25^{+}$Foxp $3^{+}$thymocytes in $\mathrm{Cx}$ and Sx rats. The central box line represents the sample median, while lower and upper borders of the box representing the 25th and 75th percentiles respectively. The lower and the upper lines indicate minimal and maximal values of the sample respectively. The figure shows data from a single experiment in which six Cx and six Sx rats were used. One further identical experiment gave very similar results. ${ }^{*} P<0 \cdot 01$.

Thymus enlargement and increased cellularity have already been reported in: (i) both mature and immature neonatally castrated rats (Leposavić et al. 1995, Shioya et al. 2000) and (ii) adult androgen-resistant (Tfm/Y) mice (Olsen \& Kovacs 1989).
It is postulated that hypercellularity in Cx rats is produced by one or more of the following mechanisms: (1) reduced thymocyte death, (2) augmented thymocyte proliferation and (3) increased entry of thymocyte precursors. The 
Table 2 Increased absolute and relative spleen weight as well as total and relative splenocyte number in 3-month-old neonatally castrated rats $(\mathrm{Cx})$ compared with age-matched sham-castrated rats $(\mathrm{Sx})$

Absolute spleen weight
(g); median (25th-75th
percentiles)

\section{Treatment}

Sx $(n=8) \quad 0 \cdot 37(0 \cdot 30-0 \cdot 40)$

$\mathrm{Cx}(n=6) \quad 0 \cdot 42(0 \cdot 41-0 \cdot 45)^{*}$

Relative spleen weight
(g/100 g bw); median
(25th-75th percentiles)
(25th-75th percentiles)

$0 \cdot 174(0 \cdot 170-0 \cdot 183)$

$0 \cdot 20(0 \cdot 19-0 \cdot 22)^{*}$

\author{
Total splenocyte number \\ $\left(\times 10^{7}\right)$ /spleen; median \\ (25th-75th percentiles)
}

$8 \cdot 25(5 \cdot 92-10 \cdot 00)$
$13 \cdot 17(12 \cdot 02-14 \cdot 75)^{*}$

\author{
Total splenocyte number \\ $\left(\times 10^{7}\right) / 100 \mathrm{~g}$ bw Median \\ (25th-75th percentiles)
}

$4 \cdot 09(2 \cdot 80-4 \cdot 66)$ $6 \cdot 26(5 \cdot 44-7 \cdot 30) *$

The table indicates data from a single experiment. Very similar data were obtained in an identically performed independent experiment. ${ }^{*} P<0 \cdot 05$; bw, body weight.

attenuated vulnerability of thymocytes from $\mathrm{Cx}$ rats to unidentified apoptotic signals in culture as well as to specific Dex-induced apoptosis supports the first option. Furthermore, since testosterone has been shown to: (i) accelerate thymocyte elimination via apoptosis and (ii) specifically target DP thymocytes for apoptosis (Guevara Patiño et al. 2000) our observed increase in the overall number and proportion of DP thymocytes in Cx rats further supports the same option. However, as an increased frequency of proliferating cells was demonstrated in ConA-thymocyte cultures from $\mathrm{Cx}$ rats, the second candidate mechanism also seems plausible. In keeping with this option are data that thymic enlargement in adult castrated mice occurs due to an accelerated rate of overall thymocyte proliferation (Olsen et al. 1994). In agreement with these findings, the percentage of $\mathrm{BrdU}^{+}$cells within none of $\mathrm{CD} 3$ subsets was shown to be significantly different between thymocyte cultures from $\mathrm{Cx}$ and $\mathrm{Sx}$ rats, suggesting that androgen deprivation affected most cell subsets that would be expected to be cycling in the normal thymus, to a quantitatively similar extent. However, neither the overall thymocyte responsiveness to ConA nor the responsiveness of any of the thymocyte subsets was altered by gonadal hormone deprivation. Although we do not have a fully satisfactory explanation for these findings, they are in line with previous data that, while some intrinsic factors that control thymocyte proliferation are obviously regulated by gonadal hormones, thymocyte mitogenic responsiveness to mitogenic ConA concentrations is relatively refractory to manipulations in the level of gonadal hormone (Windmill et al. 1993, Utsuyama et al. 1995). Finally, the third option also cannot be completely ruled out as it has been suggested that stem cell migration from the bone marrow to the thymus is an androgen-sensitive thymic epithelial cell-dependent step on the route of T-cell development (Olsen et al. 2001).

Thymic hypercellularity in Cx rats was accompanied by substantial alterations in the composition of thymocyte subsets. Despite the fact that in Cx rats a numerical increase in the TN subset was found, the proportion of these cells was reduced while the proportion and number of downstream DP cells $\left(\mathrm{TCR} \alpha \beta^{-}, \mathrm{TCR} \alpha \beta^{\text {low }}\right.$ and TCR $\alpha \beta^{\text {high }}$ ) was increased. These findings are fully consistent with the data that dihydrotestosterone treatment of adult $\mathrm{Cx}$ C57BL/6 mice produces an increase in the fraction of DN cells by nearly $35 \%$ accompanied by a decrease in the DP cell population (Olsen et al. 1991). It may be assumed that the increase in cell number and proportion of DP subsets was derived from accelerated thymocyte transition from the TN subset, the latter being maintained by recruitment of precursor cells. Our present data indicate that even if precursor immigration into the thymi of Cx rats was increased, as has been suggested (Olsen et al. 1991), it would not be sufficient to provide complete repopulation of this rapidly differentiating cell pool. Alternatively, the increase in cell number and proportions of downstream DP subsets may be due to augmented proliferation within these subsets, independent of the TN subset. However, the results obtained in thymocyte culture do not support this option.

Table 3 Absolute number and proportion of splenic lymphocytes defined by the expression of CD3, CD4 and CD8 in 3-month-old neonatally castrated rats $(C x)$ and age-matched sham-castrated rats $(S x)$

\begin{tabular}{|c|c|c|c|c|}
\hline & \multicolumn{2}{|c|}{$\begin{array}{l}\text { Percentage of cells; } \\
\text { Median (25th-75th percentiles) }\end{array}$} & \multicolumn{2}{|c|}{$\begin{array}{l}\text { Absolute number of cells } \\
\left(\times 10^{7}\right) / \text { spleen; median }(25 \text { th }-75 \text { th percentiles })\end{array}$} \\
\hline & $\mathrm{Sx}(n=8)$ & $C \times(n=6)$ & $\mathrm{Sx}(n=8)$ & $C \times(n=6)$ \\
\hline \multicolumn{5}{|c|}{ Splenocyte subset } \\
\hline $\mathrm{CD}^{+}$ & $66 \cdot 64(64 \cdot 31-69 \cdot 83)$ & $56 \cdot 44(50 \cdot 52-59 \cdot 73)^{*}$ & $5 \cdot 95(4 \cdot 33-6 \cdot 62)$ & $7 \cdot 07(6 \cdot 20-8 \cdot 81)^{*}$ \\
\hline $\mathrm{CD}^{-}$ & $33 \cdot 33(30 \cdot 14-35 \cdot 62)$ & $43 \cdot 51(40 \cdot 23-49 \cdot 28)^{*}$ & $2 \cdot 77(2 \cdot 34-3 \cdot 09)$ & $5 \cdot 86(5 \cdot 35-6 \cdot 21)^{*}$ \\
\hline $\mathrm{CD}^{-} \mathrm{CD}^{-}$ & $29 \cdot 44(27 \cdot 22-32 \cdot 71)$ & $41 \cdot 13(36 \cdot 53-46 \cdot 07)^{*}$ & $2.53(2 \cdot 04-2 \cdot 97)$ & $5 \cdot 51(4 \cdot 84-5 \cdot 85)^{*}$ \\
\hline $\mathrm{CD}^{+}{ }^{+} \mathrm{CD} 8^{-}$ & $35 \cdot 88(35 \cdot 09-36.97)$ & $27 \cdot 67(25 \cdot 77-29 \cdot 27)^{*}$ & $3 \cdot 18(2 \cdot 37-3 \cdot 49)$ & $3 \cdot 51(3 \cdot 13-4 \cdot 30)$ \\
\hline $\mathrm{CD}^{-}{ }^{-} \mathrm{CD}^{+}$ & $29 \cdot 44(27 \cdot 22-30 \cdot 26)$ & $30 \cdot 08(27 \cdot 15-33 \cdot 16)$ & $2 \cdot 49(1 \cdot 98-2 \cdot 90)$ & $3 \cdot 95(3 \cdot 33-4 \cdot 67)^{*}$ \\
\hline $\mathrm{CD}^{+}{ }^{+} \mathrm{CD}^{+}$ & $1 \cdot 60(1 \cdot 28-1 \cdot 95)$ & $0.99(0 \cdot 79-1 \cdot 38)^{*}$ & $0 \cdot 14(0.09-0 \cdot 17)$ & $0 \cdot 13(0 \cdot 09-0 \cdot 20)$ \\
\hline
\end{tabular}

The table indicates data from a single experiment. Very similar data were obtained in an identically performed independent experiment. $* P<0 \cdot 05$. 
The increase in the percentage of selected DP TCR $\alpha \beta^{\text {high }}$ cells in $\mathrm{Cx}$ rats $(\sim 20 \%)$, in light of the less-pronounced increase in the percentage of DP TCR $\alpha \beta^{\text {low }}$ cells $(\sim 7 \%)$, may suggest alterations in selection processes. Several findings support this notion. First, TCR $\alpha \beta^{+}$thymocytes from $\mathrm{Cx}$ rats exhibit markedly increased surface density expression of CD90 (Thy-1). Since thymocytes from Thy-1 ${ }^{-/}$mice have been shown to exhibit an exaggerated negative selection, most likely due to lack of Thy-1-mediated negative regulation of TCR $\alpha \beta$ signalling (Hueber et al. 1997), it may be expected that the high density of CD90 on thymocytes from $\mathrm{Cx}$ rats induced hyposensitivity to negative selection. Secondly, the decreased percentage of apoptotic cells in thymocyte cultures from $\mathrm{Cx}$ rats is also consistent with the previous hypothesis. Since noradrenaline has been shown to decrease Thy-1 mRNA levels in murine thymocytes (Wajeman-Chao et al. 1998), the increase in Thy- 1 surface density on thymocytes from $\mathrm{Cx}$ rats may be related to the decreased noradrenaline level in the thymus of these animals (data not shown).

Although neonatal castration produced an increase in the number of $\mathrm{CD} 4^{+} \mathrm{CD} 8^{-}$SP TCR $\alpha \beta^{\text {high }}$ cells but did not affect that of $\mathrm{CD} 4^{-} \mathrm{CD} 8^{+}$SP TCR $\alpha \beta^{\text {high }}$ cells, the relative proportion of both these subsets was decreased in $\mathrm{Cx}$ rats. Similar changes in the proportion of SP thymocyte subsets were found in castrated mice (Olsen et al. 1991, 1994). These findings together with: (i) the increase in both number and proportion of DP TCR $\alpha \beta^{\text {high }}$ cells as the immediate source of all mature T-cells (Shortman et al. 1991) and (ii) alterations in the numbers of cells within spleen T-cell subsets (an increased number of $\mathrm{CD}^{-}{ }^{-} \mathrm{CD} 8{ }^{+}$but an unaltered number of $\mathrm{CD} 4^{+} \mathrm{CD}^{-}$cells) suggest changes in thymocyte terminal differentiation/maturation and in emigration of the mature cells. More precisely, our study clearly suggests accelerated differentiation/maturation of DP TCR $\alpha \beta^{\text {high }}$ cells towards mature $\mathrm{CD} 4^{-} \mathrm{CD} 8^{+} \mathrm{SP}$ cells followed by their emigration and decelerated differentiation/maturation towards mature $\mathrm{CD} 4{ }^{+} \mathrm{CD} 8^{-} \mathrm{SP}$ cells providing an increase in the number of $\mathrm{CD} 4{ }^{-} \mathrm{CD}^{+}{ }^{+} \mathrm{SP}$ cells and preservation of $\mathrm{CD} 4^{+} \mathrm{CD} 8^{-} \mathrm{SP}$ cell pool in the spleen of $\mathrm{Cx}$ rats respectively. The latter assumption is supported by the data that indicate: (i) androgen deprivation in mice stimulates thymic expansion and output culminating in increased levels of newly emigrated T-cells appearing within hyperplastic peripheral lymphoid tissues and (ii) this increase in peripheral T-cells is absent when thymectomy is performed 2 weeks before castration (Roden et al. 2004). A shifted $\mathrm{CD} 4^{+} / \mathrm{CD}^{+}{ }^{+}$ratio in the spleen from $\mathrm{Cx}$ rats, due to a decreased frequency of $\mathrm{CD} 4^{+}$cells, is consistent with the findings in young testosterone-treated rats (Yao et al. 2003). However, to fully confirm the previous assumption the analysis of recent thymic emigrants in both $\mathrm{Cx}$ and Sx rats would have to be performed.

Finally, it should be emphasised that the assumed reduction in negative thymocyte selection may lead to an increased escape of potentially harmful autoreactive cells into the periphery of Cx rats. This proposal, coupled with data indicating that: (i) the relative number of thymic cells expressing the
$\mathrm{CD} 4{ }^{+} \mathrm{CD} 25^{+} \mathrm{Foxp}^{+}$regulatory phenotype is not affected by neonatal castration; (ii) the number of $\mathrm{CD} 4{ }^{+} \mathrm{CD} 25^{+}$ Foxp $3^{+} \mathrm{T}$ reg cells is unaltered, while their proportion is decreased, in the peripheral lymphoid tissues of $\mathrm{Cx}$ rats (data not shown) and (iii) in autoimmune disease models androgenic suppression of disease activity requires the presence of the thymus (Roubinian et al. 1978), suggests a misbalance in the thymic production of autoreactive and Treg cells in $\mathrm{Cx}$ rats that may be related to increased susceptibility of $\mathrm{Cx}$ animals to induction of autoimmune diseases (Olsen \& Kovacs 1996).

Furthermore, the thymic changes in neonatally castrated rats cannot be explained simply and only by the lack of testicular androgens, serum levels of which during rat postnatal development have been previously reported (Leposavić \& Mićić 1992). Several lines of evidence indicate that castrationinduced deregulation of the hypothalamic-pituitary axis may also contribute to the development/maintenance of these changes. First, both gonadotrophins and prolactin are shown to influence T-cell differentiation (Rouabhia et al. 1989, Carreño et al. 2005). Secondly, it has been demonstrated that GnRH: (i) is synthesised locally in the thymus, (ii) its thymic level increases following castration (Azad et al. 1998) and (iii) it is implicated in regulation of T-cell development (Jacobson \& Ansari 2004, Leposavic et al. 2005). Furthermore, in spite of the fact that rat T-cells are able to convert androgens to oestradiol (Samy et al. 2001) due to lack of adrenal gland contribution to plasma levels of androgen hormones in rats (van Weerden et al. 1992), a lack of regulation mediated via the oestradiol receptor (ER) $\alpha$ signalling system on postnatal thymus development (Yellayi et al. 2000) may also contribute to the observed changes in Cx rats.

In summary, our study demonstrates that neonatal castration affects thymus development and produces alterations in T-cell differentiation and selection (most likely by altering Thy- 1 expression on the selected cells) leading to an increase in the level of CD8+T-cells within the spleen. Furthermore, it appears that neonatal ablation of gonadal hormone production may distort the production of autoreactive and regulatory cells which could provide a fertile ground for the induction of autoimmune diseases.

\section{Acknowledgements}

This work was supported by project grant number 145049 from the Ministry of Science and Environmental Protection of the Republic of Serbia. We thank Dr David R Jones for proofreading the manuscript. The authors declare that there is no conflict of interest that would prejudice the impartiality of this scientific work.

\section{References}

Aboudkhil S, Bureau JP, Garrelly L \& Vago P 1991 Effects of castration, depotestosterone and androgen-resistent mice. Scandinavian Journal of Immunology $29733-738$. 
Azad N, LaPaglia N, Agrawal L, Steiner J, Uddin S, Williams DW, Lawrence AM \& Emanuele NV 1998 The role of gonadectomy and testosterone replacement on thymic luteinizing hormone-releasing hormone production. Journal of Endocrinology 158 229-235.

Beyer C 1987 Sex steroids and afferent input: their roles in brain sexual differentiation. Annual Review of Physiology 49 349-364.

Brown DG, Sun X-M \& Cohen G 1993 Dexamethasone-induced apoptosis involves cleavage of DNA to large fragments prior to internucleosomal fragmentation. Journal of Biological Chemistry 268 3037-3039.

Carreño PC, Sacedon R, Jimenez E, Vicente A \& Zapata AG 2005 Prolactin affects both survival and differentiation of T-cell progenitors. Journal of Neuroimmunology $160135-145$.

Cohen JJ 1991 Programmed cell death in the immune system. Advances in Immunology $\mathbf{5 0} 55-85$.

Čolić M, Gašić S, Vučević D, Pavičić L, Popović P, Jandrić D, MedićMijačević L \& Rakić L 2000 Modulatory effect of 7-thia-8-oxoguanosine on proliferation of rat thymocytes in vitro stimulated with concanavalin A. International Journal of Immunopharmacology 22 203-212.

Guevara Patiño JA, Marino MW, Ivanov VN \& Nikolić-Žugić J 2000 Sex steroids induce apoptosis of CD8 + CD4+ double-positive thymocytes via TNF-alpha. European Journal of Immunology 30 2586-2592.

Hueber AO, Bernard AM, Battari CL, Marguet D, Massol P, Foa C, Brun N, Garsia S, Steward C, Pierres M et al. 1997 Thymocytes in Thy-1-/- mice show augmented TCR signalling and impaired differentiation. Current Biology 7 705-708.

Jacobson JD \& Ansari MA 2004 Immunomodulatory actions of gonadal steroids may be mediated by gonadotropin-releasing hormone. Endocrinology 145 330-336.

Kamath AB, Nagarkatti PS \& Nagarkatti M 1998 Characterization of phenotypic alterations induced by 2,3,7,8-tetrachlorodibenzo-p-dioxin on thymocytes in vivo and its effect on apoptosis. Toxicology and Applied Pharmacology 150 117-124.

Kovacs WJ \& Olsen NJ 1987 Androgen receptors in human thymocytes. Journal of Immunology 139 490-493.

Laakko T, King L \& Fraker P 2002 Versatility of merocyanine 540 for the flow cytometric detection of apoptosis in human and murine cells. Journal of Immunological Methods 261 129-139.

Leposavić G \& Mićić M 1992 Testosterone binding sites in the rat thymus during late embryonal and postnatal period. Thymus 29 77-88.

Leposavić G, Karapetrović B, Mićić M \& Kosec D 1995 Prepubertal castration alters the phenotypic profile of adult rat thymocytes. NeuroImmunoModulation 2 100-107.

Leposavić G, Pekić S \& Kosec D 2005 Gonadotropin-releasing hormone agonist administration affects the thymopoiesis in adult female rats independently on gonadal hormone production. American Journal of Reproductive Immunology 53 30-41.

Maggi E, Cosmi L, Liotta F, Romagnani P, Romagnani S \& Annunziato F 2005 Thymic regulatory T cells. Autoimmunity Reviews 4 579-586.

Morale MC, Batticane N, Bartolini G, Guarcello V, Farinella Z, Galasso MG \& Marchetti B 1991 Blockade of central and peripheral luteinizing hormone-releasing hormone (LHRH) receptors in neonatal rats with a potent LHRH-antagonist inhibits the morphofunctional development of the thymus and maturation of the cell-mediated and humoral immune responses. Endocrinology 128 1073-1085.

Mower DA Jr, Peckham DW, Illera VA, Fishbaugh JK, Stunz LL \& Ashman RF 1994 Decreased membrane phospholipid packing and decreased size precede DNA cleavage in mature mouse B cell apoptosis. Journal of Immunology 152 4832-4842.

Olsen NJ \& Kovacs WJ 1989 Increased thymic size and the thymocyte interleukin 2 production in androgen-resistant mice. Scandinavian Journal of Immunology 29 733-738.

Olsen NJ \& Kovacs WJ 1996 Gonadal steroids and immunity. Endocrine Reviews 17 369-384.

Olsen NJ, Watson MB, Henderson GS \& Kovacs WJ 1991 Androgen deprivation induces phenotypic and functional changes in the thymus of adult male mice. Endocrinology 129 2471-2476.
Olsen NJ, Viselli SM, Shults K, Stelzer G \& Kovacs WJ 1994 Induction of immature thymocyte proliferation after castration of normal male mice. Endocrinology 134 107-113.

Olsen NJ, Olson G, Viselli SM, Gu X \& Kovacs WJ 2001 Androgen receptors in thymic epithelium modulate thymus size and thymocyte development. Endocrinology 142 1278-1283.

Petrie HT, Hugo P, Scollay R \& Shortman K 1990 Lineage relationships and developmental kinetics of immature thymocytes: CD3, CD4 and CD8 acquisition in vivo and in vitro. Journal of Experimental Medicine 172 1583-1588.

Pierpaoli W, Kopp HG, Muller J \& Keller M 1977 Interdependence between neuroendocrine programming and the generation of immune recognition in ontogeny. Cellular Immunology 29 16-27.

Pongracz J, Parnell S, Anderson G, Jaffrézou J-P \& Jenkinson E 2003 Con A activates an Akt/PKB dependent survival mechanism to modulate TCR induced cell death in double positive thymocytes. Molecular Immunology 39 1013-1023.

Roden AC, Moser MT, Tri SD, Mercader M, Kuntz SM, Dong H, Hurwitz AA, McKean DJ, Celis E, Leibovich BC et al. 2004 Augmentation of T cell levels and responses induced by androgen deprivation. Journal of Immunology 173 6098-6108.

Rouabhia M, Chakir J, Othmane O \& Deschaux PA 1989 Interaction between immune and endocrine systems: effect of luteotrophic hormone (LH) and thymic hormone on surface antigens (Thy1-2, Lyt1 and Lyt2) expression. Thymus 14 205-212.

Roubinian JR, Tala N, Greenspan JS, Goodman JR \& Siiteri PK 1978 Effect of castration and sex hormone treatment on survival, anti-nucleic acid antibodies, and glomerulonephritis in NZB/NZW F1 mice. Journal of Experimental Medicine 147 1568-1583.

Samy TS, Knöferl MW, Zheng R, Schwacha MG, Bland KI \& Chaudry I 2001 Divergent immune responses in male and female mice after traumahemorrhage: dimorphic alterations in $\mathrm{T}$ lymphocyte steroidogenic enzyme activities. Endocrinology 142 3519-3529.

Sasson S \& Mayer M 1981 Effect of androgenic steroids on rat thymus and thymocytes in suspension. Journal of Steroid Biochemistry 14 509-517.

Shioya N, Inomata T, Ninomiya H \& Nakamura T 2000 Influence of castration on development of the thymus in neonatal male rats. Experimental Animals 49 57-60.

Shortman K, Vremec D \& Egerton MJ 1991 The kinetics of T cell antigen receptor expression by subgroups of $\mathrm{CD} 4+8+$ thymocytes: delineation of $\mathrm{CD} 4+8+32+$ thymocytes as post-selection intermediates leading to mature $\mathrm{T}$ cells. Journal of Experimental Medicine 173 323-332.

Stephens GL \& Ignatowicz L 2003 Decreasing the threshold for thymocyte activation biases $\mathrm{CD} 4+\mathrm{T}$ cells toward a regulatory $(\mathrm{CD} 4+\mathrm{CD} 25+)$ lineage. European Journal of Immunology 33 1282-1291.

Takeda H, Chodak G, Mutchnik S, Nakamoto T \& Chang C 1990 Immunohistochemical localization of androgen receptors with monoclonal and polyclonal antibodies to androgen receptor. Journal of Endocrinology 126 $17-25$

Utsuyama M \& Hirokawa K 1989 Hypertrophy of the thymus and restoration of immune functions in mice and rats by gonadectomy. Mechanisms of Ageing and Development 47 175-185.

Utsuyama M, Hirokawa K, Mancini C, Brunelli R, Leter G \& Doria G 1995 Differential effects of gonadectomy on thymic stromal cells in promoting $\mathrm{T}$ cell differentiation in mice. Mechanisms of Ageing and Development $\mathbf{8 1}$ 107-117.

Verthelyi D 2001 Sex hormones as immunomodulators in health and disease. International Immunopharmacology 1 983-993.

Viselli SM, Olsen NJ, Shults K, Steizer G \& Kovacs WJ 1995 Immunochemical and flow cytometric analysis of androgen receptor expression in thymocytes. Molecular and Cellular Endocrinology 109 19-26.

Wajeman-Chao SA, Lancaster SA, Graf LH Jr \& Chambers D 1998 Mechanism of catecholamine-mediated destabilization of messenger RNA encoding Thy-1 protein in T-lineage cells. Journal of Immunology 61 4825-4833.

van Weerden WM, Bierings HG, Van Steenbrugge GJ \& De Jong FH 1992 Adrenal glands of mouse and rat do not synthesize androgens. Life Sciences $\mathbf{5 0} 857-861$ 
Windmill KF, Meade BJ \& Lee VWK 1993 Effect of prepubertal gonadectomy and sex steroid treatment on the growth and lymphocyte populations of the rat thymus. Reproduction Fertililty and Development 5 73-81.

Yao G, Liang X, Han H \& Hou Y 2003 In vivo modulation of the circulating lymphocyte subsets and monocytes by androgen. International Immunopharmacology 3 1853-1860.

Yellayi S, Teuscher C, Woods JA, Welsh TH Jr, Tung KS, Nakai M, Rosenfeld CS, Lubahn DB \& Cooke PS 2000 Normal development of thymus in male and female mice requires estrogen/estrogen receptor-alpha signaling pathway. Endocrine 12 207-213.
Zamoyska R \& Lovatt M 2004 Signalling in T-lymphocyte development: integration of signalling pathways is the key. Current Opinion in Immunology 16 191-196.

Received in final form 7 December 2006

Accepted 20 December 2006 Made available online as an Accepted Preprint 27 December 2006 